\title{
Advancing a Political Ecology of Global Environmental Discourses
}

\author{
W. Neil Adger, Tor A. Benjaminsen, Katrina Brown \\ and Hanne Svarstad
}

\begin{abstract}
In the past decade international and national environmental policy and action have been dominated by issues generally defined as global environmental problems. In this article, we identify the major discourses associated with four global environmental issues: deforestation, desertification, biodiversity use and climate change. These discourses are analysed in terms of their messages, narrative structures and policy prescriptions. We find striking parallels in the nature and structure of the discourses and in their illegibility at the local scale. In each of the four areas there is a global environmental management discourse representing a technocentric worldview by which blueprints based on external policy interventions can solve global environmental dilemmas. Each issue also has a contrasting populist discourse that portrays local actors as victims of external interventions bringing about degradation and exploitation. The managerial discourses dominate in all four issues, but important inputs are also supplied to political decisions from populist discourses. There are, in addition, heterodox ideas and denial claims in each of these areas, to a greater or lesser extent, in which the existence or severity of the environmental problem are questioned. We present evidence from location-specific research which does not fit easily with the dominant managerialist nor with the populist discourses. The research shows that policy-making institutions are distanced from the resource users and that local scale environmental management moves with a distinct dynamic and experiences alternative manifestations of environmental change and livelihood imperatives.
\end{abstract}

\section{INTRODUCTION}

At the United Nations Conference on Environment and Development in 1992, world leaders and environmentalists, from Maurice Strong to Fidel Castro, roused the world with optimism for a future for the planet based on universal principles of sustainability and environmental rights. Tackling the major issues of global environmental change was one of the key actions in implementing sustainable development. But the rhetoric of $\mathrm{UNCED}^{1}$ was

1. We recognize that global environmental debates did not simply begin in 1992. Rather, UNCED comprised the culmination of debates over the past three decades. These ideas

Development and Change Vol. 32 (2001), 681-715. (C) Institute of Social Studies 2001. Published by Blackwell Publishers, 108 Cowley Road, Oxford OX4 1JF, UK. 
almost exclusively dominated, we would argue, by the belief that these socalled global environmental problems are in some way 'solvable' through globally co-ordinated action. Almost a decade later, global environmental problems remain as intransigent as ever, but the managerial language continues to dominate debates about progress. In this article we dissect some of the key components of the debates as they have been played out in policy and practice. We argue that environmental change at the local level is largely illegible through the lenses either of the dominant managerial discourse or of the populist alternatives that we identify. Attempts to standardize ideas and ways of constructing reality have been observed both in policy domains and in the role of the state in modernization and development (Scott, 1998). Our notion of illegibility of local level adaptation resonates with those of Scott (1998) on deliberate ordering of the process of development to enhance 'legibility'.

We undertake this analysis by examining four major environmental issues: deforestation, desertification, biodiversity utilization and climate change. The analysis is framed within the general approach of political ecology (Blaikie and Brookfield, 1987; Bryant and Bailey, 1997; Peet and Watts, 1996; Stott and Sullivan, 2000) by linking the underlying discourses of environmental change to policies and institutions engaged in implementing environment and development. Peet and Watts (1996), in reviewing the frontiers of political ecology, argue that discursive approaches to the analysis of environment and development are central to this emerging discipline. This area of political ecology includes research on the sociology of science and knowledge, on the history of institutions and policy on environment and development and, most importantly, on the globalization of environmental discourses in relation to 'new languages and institutional relations of global environmental governance and management' (ibid.: 11). Likewise, to Stott and Sullivan (2000: 2), political ecology is 'a concern with tracing the genealogy of narratives concerning "the environment", with identifying power relationships supported by such narratives, and with asserting the consequences of hegemony over, and within, these narratives for economic and social development, and particularly for constraining possibilities for self-determination'.

A key issue within political ecology is the exploration of multi-level connections between global and local phenomena, not only in environmental functions but also in decision-making and hierarchies of power. The sections which follow articulate the global and international discourses surrounding global environmental change and the multi-levelled actions and interactions linking these to the examples of locally experienced environ-

can be traced back to milestone events and reports such as the Stockholm Conference on the Human Environment in 1972, the report of the Club of Rome of 1973, the World Conservation Strategy of the IUCN of 1980 and its follow-up Caring for the Earth issued by IUCN, UNEP and WWF (1991), the Brundtland report of 1987 (WCED, 1987), and finally the UNCED conference in Rio de Janeiro in 1992. 
mental change. We argue that since global discourses are often based on shared myths and blueprints of the world, the political prescriptions flowing from them are often inappropriate for local realities. The connections at multiple levels come through the actions and practices of government agents, individuals and civil society, and the alliances formed between them. In this article we define discourses as knowledge regimes and explore the impacts of policies which are derived from these. In adopting this approach we recognize that there is an emerging debate concerning the complex evolution and interactions between knowledge and policy (see, for example, Keeley and Scoones, 2000; Robbins, 2000).

The four issues we examine - deforestation, desertification, biodiversity utilization and climate change - are central to current debates in the area of environment and development at all scales. It is important to note that the four issues are linked - in terms of the biophysical processes underlying them; in terms of the environments where these changes are observed; and in terms of the institutions which have interests or which seek to manage and appropriate resources associated with them. The next section outlines discourse analysis as the methodological framework for our analysis. We then introduce the main discourses identified in each of the four areas. These descriptions outline the narratives, narrative structure and interventions and policies associated with the discourses concerning the four issues. We then examine the similarities and differences between the discourses, the linkages between them and the implications of the main discourses for environment and development policy.

\section{DISCOURSE ANALYSIS CONCERNING ENVIRONMENT AND DEVELOPMENT}

We broadly define discourse as a shared meaning of a phenomenon. This phenomenon may be small or large, and the understanding of it may be shared by a small or large group of people on a local, national, international or global level. The actors adhering to the discourse participate in various degrees to its production, reproduction and transformation through written and oral statements. ${ }^{2}$ In this article, we focus on major global discourses concerning the four global environmental issues. In the environmental arena, discourse analyses and related approaches have been used to characterize

2. Discourse analysis is an example of constructionist approaches to the study of the social world which focus not directly on a specific phenomenon itself, but rather on claims concerning this phenomenon, claims-makers and the claims-making process (Best, 1989; Hannigan, 1995). Michel Foucault's historical examination of social phenomena, such as sexuality, imprisonment and punishment, and government (Foucault, 1979, 1984, 1991), represent classics in discourse analysis. Roots can also be traced back to early analyses of ideology and rhetoric as well as later contributions in the sociology of science, language philosophy and the post-positivist interpretative tradition (Hajer, 1995: 43). 
pervading and received wisdoms (Leach and Mearns, 1996), the evolution of environmental crises and their social construction (Roe, 1991, 1995, 1999). Other examples here are in areas such as the science surrounding ozone layer depletion (Litfin, 1994) and acid rain (Hajer, 1995). At a more general level, Dryzek (1997) draws a distinction between main discourses countering the prior 'modern' hegemonic discourse of industrialism. Related to these, O'Riordan (1983) draws out the philosophical underpinnings of ecocentrism and technocentric views of the physical world to explain science, public policy and action in resource use and environmental protection. ${ }^{3}$

In the 1990s the discourses of global environmental change moved to the centre ground of environmental debates, leading to global-scale solutions for what are perceived to be significant environmental problems. It has been argued that this is, in part, a result of scientific advance in detecting global environmental change phenomena such as climate change, and the rise of global-scale scientific endeavours (Shackley and Wynne, 1995). Other motivations may simply be associated with economic and cultural globalization. Taylor and Buttel (1992) and Goldman (1998) question this hegemony of global environmental change. Goldman argues that the science contributing to this debate is simply another facet of a new dominant paradigm where commons management is a panacea and antidote to all threats. Further, he argues that the emerging global commons paradigm is driven by interests that seek to colonize and extract from global commons that were previously only locally controlled.

Discourse analysis 'has come to mean many different things in as many different places' (Hajer, 1995: 43). In this article we consider the following three elements to represent the main aspects of discourse analyses: analysis of regularities in expressions to identify discourses; analysis of the actors producing, reproducing and transforming discourses; and social impacts and policy outcomes of discourses. The discursive formations in the environmental issues covered in this article all focus to some extent on the rural poor in developing countries. The analysis deliberates on the social implications of the discourses for this broad group. In describing the discourses, we present data concerning all three elements outlined above, but we particularly focus on identifying the main characteristics of the discourses and their social impacts and outcomes. In order to focus on our comparative analysis of the features of the discourses within the four issues, the scope of this article is limited to how the various discourses evolve and interact on multiple scales rather than analysing directly the complex relationship between discourse and policy formulation.

3. A further set of analyses comes from critiques of the processes of social and economic development. Analysis of the discourses in development policies have been undertaken, for example, by Ferguson (1990) and Grillo and Stirratt (1997), and on the interaction of knowledge with policy at the environment-development nexus (Leach and Mearns, 1996; Peet and Watts, 1996). 
A discourse contains a corpus of expressions in which we can find homogeneity in message as well as in expressive means. ${ }^{4}$ Homogeneity in message implies that the expressions share a certain knowledge and perception of the phenomenon in question, and there may also be shared beliefs concerning causes of problems and appropriate responses. The homogeneity in message constitutes the characteristics of a discourse as a truth system. Our analysis in the following sections addresses how perceptions and concerns for the environment are expressed and how external interventions are perceived. The term expressive means refers to the ways the message of a discourse is communicated. Within discourse analysis, expressive means have been analysed in terms of narratives (Petersen, 1997), story-lines (Hajer, 1995) and metaphors, and other rhetorical devices (Dryzek, 1997). Here we concentrate the presentation and analysis on narratives, of which two aspects are important.

First, a narrative is a story with a chronological order (beginning, middle and end). Roe, for example, defines the concept of 'development narrative' in which chronology is emphasized (Roe, 1991, 1995). Roe draws attention to political implications of development narratives, such as the appeal of the 'tragedy of the commons' to privatization and livestock controls. He stresses that a development narrative is not necessarily displaced by negative findings that seems to refute it. Roe therefore proposes to create 'counternarratives' that tell a better story. He further proposes that, when appropriate, researchers should 'denarrativise' by insisting that 'there is no story to tell until the facts are in' (Roe, 1991, 1995, 1999).

Second, a narrative constitutes a particular structure with respect to an involved 'cast' of actors. This aspect is derived from narratology and social semiotics in which patterns of casts and other features in expressions have been used to analyse social phenomena as diverse as fairy-tales and MTV (Berger, 1997; Petersen, 1997). Our analysis is limited to exploring whether the narratives of our selected discourses reflect patterns concerning the involvement of the archetypes heroes, villains and victims. ${ }^{5}$

A discourse may be labelled hegemonic if it dominates thinking and is translated into institutional arrangements. A weaker form of hegemony might be labelled discursive domination (Hajer, 1995: 60-61). As Thompson and Rayner (1998) argue, plurality in discourses can be difficult to discern at particular times because all voices are forced to use the vocabulary of the dominant discourse. In the analysis here, we attempt to define dominating and challenging or alternative discourses in each of the four areas. This methodological framework is applied in the following sections. The voluminous policy and popular debates on global environmental change

4. The analytic framework for discourse analysis applied here is described in more depth in Svarstad (forthcoming).

5. Such archetypes may also be reflected in statements of the discourses that are not expressed in complete narratives. 
necessitate a partial and selective account of the major discourses, their narratives and social outcomes. First we outline each of the policy areas and identify the dominant and alternative discourses within them, before seeking parallels and wider lessons.

\section{Deforestation}

The issue of deforestation became a touchstone for environmental activism and the development of thinking on global environmental change as it emerged as a global environmental issue during the 1980s. In the late 1970s and early 1980s, for example, Myers highlighted the impacts of large-scale and rapid deforestation in tropical forests (Myers, 1979), particularly on the loss of species (Myers, 1984). During the next decade, observed high rates of forest conversion were linked to loss of biodiversity, climate change and to other aspects of environmental degradation such as soil erosion, floods and water availability. Discourses on deforestation have strong linkages with those on biodiversity loss, climate change and desertification, not only in terms of parallels in their rise and rhetoric, but also in linking the outcomes of the physical and environmental processes. Deforestation since that time has been presented as a global 'problem' - attention in the North has often focused on the destruction of tropical rainforests, with Amazonia, the Congo basin and South East Asia being identified as three key areas where change is especially widespread and rapid. In the 1990s the focus has been broadened and northern temperate forests are included in classifications of 'Frontier Forests' (Bryant et al., 1997).

Attributing cause of forest loss is a key feature of the discourses on deforestation. The burgeoning literature on forest cover change identifies a range of agents and causes of deforestation (Angelsen and Kaimowitz, 1999; Brown and Pearce, 1994) including population increases, migration, land tenure, forest products trade, infrastructure development and government policies including subsidies. These agents and causes, it is argued, are regionally differentiated (Bawa and Dayanandan, 1997) and often act in combination (Allen and Barnes, 1985). Various conceptual models have sought to elucidate causal links (for example, Bilsborrow and Geores, 1994; Bromley, 1998; Palo, 1994). In Africa, small-scale subsistence farming is generally identified as the most important cause of deforestation (Kaoneka, 1998), though this is regarded as being fuelled by rapid population growth and poverty. The activities of logging companies and smallholders and migrant farmers have been identified as among the causal factors.

Two distinct deforestation discourses are discernible. The first - and the dominant - discourse views slash and burn farmers as the main cause of the destruction of vast tracts of forest. Myers (1994), for example, speaks of 'shifted cultivators'. This perspective links poverty, environmental degradation, government and market failures and environmental security to changes 
in forest cover. It sees deforestation as a global environmental problem and uses a range of crisis narratives to propel global (read Northern) action to stem deforestation and the environmental catastrophe associated with it. This is a neo-Malthusian and managerial discourse, as it portrays a spiral of over-population and consumption as inevitably leading to forest cover loss and hence to global environmental crisis.

A second, populist discourse accepts deforestation as a serious environmental problem but views the causes differently. It presents small farmers and land managers not as the active agents of change but rather as victims, driven, through no choice of their own, to destructive practices (Colchester and Lohmann, 1993; Marglin and Marglin, 1990). The real culprits are logging companies and the trans-national interests that finance and fuel their operations. Consumption in the North drives the trade in tropical timber and the exploitation of tropical forests. Local actors and particularly indigenous forest dwellers are forced to abandon their environmentally benign 'traditional' land use practices and are displaced by logging companies, cattle ranchers and cash crop plantation operators who push aside these disempowered forest users as they convert the rich 'pristine' forest to feed their greed. The narrative associated with this discourse presents this process as vicious and violent, often involving the massacre and 'ethnic cleansing' of indigenous people. The populist discourse thus presents indigenous people as heroes, and timber companies and ranchers as villains (see Brown and Rosendo, 2000; Conklin and Graham, 1995).

Both of these deforestation discourses have powerful narratives and metaphors associated with them. Pictures of smoking remnants of forest are juxtaposed with aerial shots of dense canopies shrouded in cloud and colourfully painted indigenous people at one with nature. They both embody particular myths of nature, with notions of climax forest, stability, fragility of forest ecosystems justifying the need for concerted action and the supporting crisis narratives of irreversible change and system-wide destruction. Tropical forests are portrayed as the 'lungs of the world' in terms of their contribution to the global carbon cycle.

Examination of the outcomes of policy and practice based on the different discourses (the implementation of practice bound up with the knowledge regimes) expose their shortcomings. A case study of forest conversion processes in Cameroon, for example, reported in Brown and Ekoko (2001) and Brown and Lapuyade (2001), examines actors and interactions in three villages in humid forest areas. This study elucidates the micro-scale experiences and interactions concerning local actors and deforestation. The research runs counter to the simplified picture of change presented by both the neo-Malthusian and the populist discourses. Current estimates place deforestation rates in Cameroon at approximately $1300 \mathrm{~km}^{2}$ per year (or 0.6 per cent of total forest area per year) between 1990 and 1995, with the major causes cited as population growth and shifting cultivation (World Bank, 1999). But these estimates mask a complex political economy of 
winners and losers. A range of impacts result from the interactions and presence of logging companies in forest areas in Cameroon. The presence of greater numbers of migrants, for example, provides markets for local produce as recorded in each of the villages, at least on a temporary basis. Fieldwork in central Cameroon demonstrates that whilst villagers in central Cameroon fondly remembered the early days of logging as boom years, the present situation after two decades of logging activity means there are fewer benefits for local people, and increasing resentment (Brown and Ekoko, 2001). A myriad of informal contacts between different actors determines the overall architecture of social and economic relations associated with forest resource use. For example, an international logging company was active in central Cameroon between 1975 and 1985 and was almost unanimously considered to have brought some benefits in terms of social development. The perceptions of householders were that the majority of the company's employees were from the village, and that the local economy was 'booming' (Brown and Lapuyade, 2001).

Logging clearly impacts on land use and resource management practices of local actors. Roads provide access and a means of 'bringing the market closer'; enhanced access to forest for agriculture; and increased migration. These factors are, of course, inextricably linked themselves. However, these impacts are socially differentiated between villagers according to gender and age (Brown and Lapuyade, 2001). It also appears that the presence of logging companies in the humid forest zone in Cameroon has contributed to more general changes in the way local people perceive and relate to the forest. Residents now recognize financial and economic values in the forest and realize that there are many commodities associated with the forest. Interaction with logging companies can, in certain circumstances result in a greater conservation consciousness, while in other areas it merely leads people to exploit valuable resources more quickly. These observations demonstrate that the portrayal of external agents and local forest dwellers as either victims or villains in neo-Malthusian and populist accounts of deforestation ignore the complexity and symbiosis in social interactions in forest frontier areas.

Research in the so-called 'ageing forest frontier' in Amazonia (Brown and Muchagata, 1999) also shows how forest users do not conform to either stereotype presented by the discourses. Smallholder farmers in the Maraba region of eastern Amazonia value forest resources but the external markets for livestock products make conversion of forest to pasture economically attractive in the short term. Secure livelihoods in isolated forest frontier regions require greater emphasis on short-term income generation than long-term forest conservation, given the current policy and economic conditions. Colonist farmers in this region have, however, successfully campaigned for the establishment of an agro-extractivist reserve in order to collectively manage and sustainably utilize areas of forest and to defend forest from conversion by other, more powerful land users such as cattle 
ranchers. At the same time colonist smallholders depend on large-scale ranchers as a market for calves, so there are some aspects of co-existence between the different actors.

Hence the micro-level dynamics of forest use, even when contributing to apparent 'deforestation' in the two examples from Central Africa and Amazonia, demonstrate the irrelevance of the global discourses (both neoMalthusian and populist) in explaining dynamic local power relations and environmental outcomes. Migration, economic security and access and rights to resources are the key issues. Thus the conventional wisdom promoted by the two conventional deforestation discourses have features in common. They rarely disaggregate the complex range of actors but rather portray them as an unsustainable forest industry (from producers to consumers) and forest dwellers. They generally fail to recognize the dynamics of relationships and change and assume simplistic links between cause and effect for forest over change.

\section{Desertification}

The idea that local over-exploitation causes desert encroachment and dryland degradation in general was primarily 'established' during European colonization of Africa. During the French occupations in West Africa, colonial foresters and administrators perceived clear signs of indigenous environmental mis-management and subsequent desert advance. In 1907, a forestry mission lead by J. Vuillet, chief of Service de l'Agriculture in the colony Haut-Sénégal et Niger, stated: 'It is indeed true. The Sahara progresses toward the South; and that because of Man's action'. ${ }^{6}$ This idea was later regularly supported by colonial administrative reports, research reports (such as Aubreville, 1949; Stebbing, 1938) and travel accounts (for example Bovill, 1921). While the idea received less attention during the decade of exceptionally high rainfall in the 1950s, the droughts in the 1970s and 1980s led to a resurrection of the term and belief in 'desertification'.

The United Nations Environment Programme (UNEP), which had been created after the Stockholm Conference on the Human Environment in 1972, believed 'desertification' to be one of the main reasons for its existence. ${ }^{7}$ The organization convened the UN Conference on Desertification in Nairobi in 1978 and commissioned several studies to document the extent of desertification (for example, Lamprey, 1975; Mabbutt, 1984). Furthermore, at UNCED in 1992, desertification emerged, together with biodiversity and

6. Centre des Archives d'Outre-Mer, Aix-en-Provence, Affaires économiques, R24 (14 MI 1566), Mission forestière, 1907.

7. 'Desertification ... is probably the greatest single environmental threat to the future wellbeing of the Earth', Peter Shaw Thacher, Deputy Executive Director of UNEP (Shaw Thacher, 1979). 
climate change, as a new issue ripe for an international environmental convention. ${ }^{8}$ Chapter 12 of Agenda 21 focuses on desertification and claims that one-quarter of the total land area of the world is impacted by the process. The Secretariat of the UN Convention to Combat Desertification, which came into force in December 1996, states that 250 million people are directly affected by desertification and that one billion are at risk. ${ }^{9}$ Two discourses with attached narratives supporting the idea of desertification can be identified. First, the neo-Malthusian discourse depicts over-population in drylands as the main problem. A short version of the standard narrative says, for instance: '[The Sudano-Sahelian] belt features one of the most rapid annual population growth rates of the continent, despite the fact that in many areas the mainly rural population ... is already beyond the carrying capacity at current technological levels. This growth has resulted in a downward spiral of extensive land degradation and fuelwood shortage' (World Bank, 1996: 24).

A second, populist discourse explains land degradation by marginalization of smallholders and pastoralists caused by colonial and subsequent neocolonial exploitation. Its narrative can be seen as running directly counter to the neo-Malthusian discourse focusing on political factors instead of population growth, but without questioning the idea of desertification itself:

In West Africa, colonial administrations imposed on local farmers monocultures of annual crops for export, notably peanuts for cooking oil and livestock feed and cotton for French and British textile mills. But growing the same crops year after year on the same land, without any mixing of or rotation of crops, trees and livestock, rapidly ruined the soils. Just two successive years of peanuts robbed the soil in Senegal of almost a third of its organic matter. Rapidly depleting soils drove farmers to push export crops onto even more vulnerable lands ... Furthermore, the spread of export crops, by crowding livestock herders into even smaller areas, has contributed to overgrazing. (Lappé et al., 1998: 42-43)

Both these discourses are supported by a number of narratives on the severity, extent and causes of desertification and land degradation. The most famous and often-repeated story relating to desertification concerns the observations of an ecologist, Hugh Lamprey, in a reconnaissance flight over an area in the Sudan in 1975. The story has been used extensively to present the extent of desertification. Lamprey was assigned by the UN to give an estimate of desert encroachment. Using a light aircraft he compared what he

8. Desertification was added to the global agenda at UNCED because of African persistence and because the US unexpectedly supported the African position (Porter and Brown, 1996). This support came, it is believed, in response to the environmental criticism the US had received for failing to support the Biodiversity Convention and for dragging its feet in the preparations for the Climate Change Convention (Carr and Mpande, 1996). The concession of US support for a desertification convention can also be interpreted as part of a trade-off between North and South - the EU and the US expected African states to be supportive regarding the remaining issues in the Rio Declaration. Thus we recognize the desertification crisis rhetoric is directly tied to the political and managerial outcomes.

9. See the Convention to Combat Desertification at http://www.unccd.ch/. 
observed in 1975, which was just after a severe drought, with a vegetation map from 1958, at the end of an exceptionally wet decade in the Sahel. The conclusion drawn was that the Sahara had moved south by $90-100 \mathrm{~km}$ from 1958 to 1975 . This implied an average desert advance of 5-6 km per year (Lamprey, 1975). Subsequently, these data have been widely-quoted by governments, international aid donors and the media, and have entered school textbooks as an example of irrefutable facts pointing to a global environmental crisis. This is an apposite example of how a single narrative has contributed significantly to the institutionalization of a crisis discourse.

The time-scale chosen within a highly fluctuating and unstable environment is one obvious problem with Lamprey's study, when the results are extrapolated to longer time periods and to larger areas. It becomes even more problematic when the observed changes are explained by human action: 'the sand encroachment problem cannot be attributed only to recent mistakes but is the result of several thousand years of abuse of the fragile ecosystems which formerly existed in the Sahara and Nubian areas' (Lamprey, 1975: 4).

Both the neo-Malthusian and populist discourses on desertification have proven to be powerful and have informed state intervention and the aid industry. They are, however, presently being challenged as evidence is amassed against their main tenets. During the past decade new research has undermined the idea of human-induced desertification (see, for instance, Behnke and Scoones, 1993; Helldén, 1991; Mortimore, 1989, 1998; Oba et al., 2000; Swift, 1996; Warren and Khogali, 1992). This research recognizes the resilience and variability of drylands and stresses the need for flexibility in coping with a highly unstable environment. Hence, empirical observation illustrates the contrast between the general desertification discourses and processes identified 'on the ground' as well as the policy implications and local impacts of the general discourses.

In Mali, neo-Malthusian assumptions about fuelwood use have been tested in two regions by Benjaminsen (1993, 1996, 1997a). Both regions are frequently mentioned as extreme cases of escalating fuelwood needs causing deforestation. But field research in the Gourma region in northern Mali detected no relationship between use and deforestation (Benjaminsen, 1993, 1996). All wood used in local households was dry wood collected from dead trees. The generous amounts of dead wood available are a consequence of the fluctuating rainfall in the Sahel and the frequently occurring droughts. The other region studied, the cotton zone in southern Mali, is one of the most densely populated and most intensively cultivated areas in the country. Rural domestic fuelwood use is often stressed in presentations by aid donors, forest authorities and external consultants as one of the main causes of deforestation in the region. Since dead wood available does not suffice to cover needs, green wood is also cut for fuelwood in the cotton zone. However, by comparing data from fifty villages, it was found that estimated consumption of green wood was generally well below forest regeneration. Only in one sub-zone, which is close to a major road, causing external 
pressure on the forest by commercial exploitation of wood for sale in urban centres, did fuelwood depletion occur (Benjaminsen, 1997a).

This evidence for resilient social and natural systems contradicts the neoMalthusian discourse. But the developments in the Malian cotton zone also represent an empirical case questioning some of the simplistic relationships put forward in the populist discourse (Benjaminsen, 2001a, 2001b). After several decades of colonial attempts to intensify cotton production, including coercion during 1912-46, production finally took off in the late 1950s due to increased prices. In 1958, production of export cotton from Mali was 3900 tons and 40 years later it had risen to around 0.5 million tons. This development has also been of benefit to the food crops grown in the cotton zone. In fact, there has been a significant growth in grain production in the entire zone, as a residual effect of intensified cotton cultivation, which has led to increased self-sufficiency during the last decades (Dioné, 1989; Raymond and Fok, 1995). In this way, the cotton zone has become a net exporter of grains to other parts of the country as well as to neighbouring countries.

Despite cotton expansion resulting in Mali becoming sub-Saharan Africa's largest cotton producer, the system does not imply monoculture without any mixing or rotation of crops, trees and livestock, as cotton is grown in rotation with maize or with millet or sorghum. Farm trees, such as Acacia albida (known by farmers to increase soil fertility), Parkia biglobosa (producing fruits used to make a sauce) and Butyrosperum parkii (producing nuts used to make shea butter) are actively protected. The result is a typical landscape of parkland in large parts of the Sudano-Sahelian zone of West Africa. Smallholders have also, in the past decade, begun to plant trees to delimit their fields. Cattle used as draught animals are highly integrated in the agricultural system and manure from the cattle kraals is collected and spread on the fields. In addition, organic manure from agricultural residues and chemical fertilizers are applied extensively and at increasing rates (Benjaminsen, 2001a, 2001b). Hence, cash-crop cotton cultivation does not have a clear soil mining effect in contrast to the claims of the populist discourse.

In a review of the neo-Malthusian desertification discourse, Swift (1996) attributes the robustness and widespread acceptance of the discourse to the fact that it was created by and was convenient for the interests of three main groups of actors: colonial and national governments; international aid donors, especially UN agencies; and some scientists. These actors are the winners, while the losers emerging from the discourse have been Sahelian farmers and pastoralists. In the Malian National Plan to Fight Desertification and the Advancing Desert (1985-2000), desertification is even considered the main cause of underdevelopment itself: 'desertification is the catalysor of our underdevelopment. The phenomenon is so important that it questions the very foundation of our existence' (République du Mali, 1985: 1). Since the root cause was seen to be human over-exploitation, it was important to take action by controlling this over-use. Farmers and pastoralists have been the losers of the resulting environmental policy. 
In Mali, severe restrictions and fines are imposed on local resource use (Benjaminsen, 2000). The French colonial forest legislation was primarily concerned with conservation. It was generally assumed by colonial authorities that Sahelian populations were causing land degradation through overuse of the resource base. Therefore, a system of permits for use and fines for rule violation was created. The Forest Service, created under the Forest Decree of 1935 to implement the forest policy, recruited its agents from the military and the police. Its role as forest police rather than as extension service continued through the colonial period and persisted after independence. In 1986, in a period in which 'the global environment' was emerging as a major international topic, the Malian forest legislation was made even stricter with extremely high fines compared to the income level in Mali. The former president Moussa Traoré (in power from 1968 to 1991) became a concerned 'environmentalist' during the 1980s. The high fines imposed on cutting branches and on forest fires can be seen as an attempt to please the international community and to appeal for foreign aid and project funding (Ribot, 1995).

The forest law of 1986 completely banned all bush fires. Villages had to pay fines of FrF 6000 if forest agents discovered that there had been a fire on the village land. However, farmers and pastoralists in southern and central Mali depend on fires set at the end of the rainy season for the management of pastures. The new forest law also made wood-saving stoves compulsory. From March 1987, households without such stoves were fined FrF 100. This policy was based on the assumption that there is widespread deforestation caused by household fuelwood consumption. According to the policy, it was also illegal to cut trees or collect dry wood for sale without permission from the Forest Service. Farmers were even required to secure permits to cut or use trees they had planted themselves on their land. It was, however, formally allowed to collect dead wood for one's own consumption, but even this could be subject to an arbitrary fine demanded by the powerful forest agents. The extensive mandate allocated to the Forest Service was justified by the necessity to fight desertification. Thus the implementation of national level policy is a direct outcome of the dominant neo-Malthusian discourse, backed by international institutions and processes that promote the management of the global problem of desertification.

\section{Biodiversity Use}

The loss of biodiversity ${ }^{10}$ has been highlighted as one of the primary consequences of deforestation, but has taken on a life of its own through the 1980s and 1990s, given impetus by the Convention on Biological Diversity.

10. Biological diversity - biodiversity — is defined in terms of the diversity both within and between species, living genetic material and ecosystems (Wilson, 1992). 
One identifiable response to concern over biodiversity loss is that sustainable utilization of biodiversity can generate national and local benefits without representing a threat to its continued existence. Although natural ecosystems have been explored and exploited for useful natural products by humans throughout history, we use the term bioprospecting as it has been defined only from the 1990s - the exploration of biological resources for commercial use. Critically bioprospecting has been claimed to constitute such a sustainable activity. This section identifies and explores the rhetoric within what we define the bioprospecting discourse and the counter views within the biopiracy discourse.

Bioprospecting and its links to conservation were first espoused by interested scientists in the late 1980s and 1990s (Eisner, 1989, 1991). Eisner (1989) named the activity chemical prospecting and proposed that it be substantially intensified because of concerns over species extinction and the concomitant loss of genetic material of great value for human society in the form of new products in biomedicine. He argued for the establishment of screening laboratories in the South that could support conservation programmes (Eisner, 1991).

The rhetoric embodied in the promotion of activities to enhance sustainable utilization was adopted in a wholesale fashion into the Convention on Biological Diversity. Its objectives include the conservation of biodiversity, sustainable use of its components and fair and equitable sharing of the benefits from the use of genetic resources (UN Convention on Biological Diversity, 1992: Article 1). Several commentators believe bioprospecting to be an activity which may contribute to all three objectives and with particular reference to poor but biodiversity-rich countries in the South. At the same time, bioprospecting has the potential, it is argued, to provide the world with new medicines and companies with income (Baker et al., 1995; ten Kate, 1995; Mugabe et al., 1997; Reid et al., 1993). Such viewpoints are adopted by many conservation organizations (Jeanrenaud, 1998), as well as by those directly involved in promoting and undertaking bioprospecting activities. Hence, the main message of the bioprospecting discourse is that bioprospecting provides opportunities for a super 'win-win' situation. However, it is recognized that a critical pre-requisite for the realization of the benefits is the appropriate institutional environment in the source countries.

Narratives within this discourse are presented as cases to show how bioprospecting can lead to sustainable utilization of biological resources. These are stories usually presented by involved actors, and they are often written in an academic style. An often-told tale concerns the 1991 agreement between the Costa Rican institute INBio and the US pharmaceutical company, Merck. INBio received US $\$ 1.1 \mathrm{~m}$ for collection and preparation of samples for Merck, and INBio agreed that 10 per cent of the up-front benefits and 50 per cent of any royalties would be given to institutions to promote conservation within Costa Rica (Mateo, 2000; Reid et al., 1993). 
Shaman Pharmaceuticals, and its related organization, The Healing Forest Conservancy, have also produced a number of such narratives based on their own experiences with bioprospecting and benefit sharing. ${ }^{11}$ Unique to these narratives is the characterization of the exchanges with the term 'reciprocity'. Furthermore, while INBio stresses conservation as a major target for benefits, in Shaman Pharmaceuticals' description of recipients of benefits, emphasis is given to so-called 'indigenous, tribal or native' people (Moran, 1997: 246). Shaman Pharmaceuticals has presented its own stories about bioprospecting and reciprocity from experiences in countries such as Ecuador, Belize, Nigeria and Tanzania.

The bioprospecting narratives identify two groups of heroes. The first group comprises the bioprospectors themselves who share benefits with recipients in source countries. The second group includes local healers and others who contribute knowledge of medicinal plants and traditional knowledge of plant use, and who thereby inadvertently promote conservation. Bioprospecting is seen as one of the solutions to circumstances where local economic activities indirectly cause biodiversity loss. These narratives concentrate on bioprospecting as a positive activity, and no direct villains or victims are identified.

In the forefront of the construction of the biopiracy discourse is a group of NGOs led by the Rural Advancement Foundation International (RAFI) in North America and Genetic Resources Action International (GRAIN) operating from Europe. The metaphor of 'biopiracy' signals an activity implying plundering of poor people and countries. RAFI invented the term as a response to the managerial discourse encapsulated in the book by Reid et al. (1993) (see Mooney, 2000). In 1994 RAFI referred to concern from the North (particularly the US) about loss of royalties through pirated pharmaceuticals and agricultural chemicals. RAFI compares this to what it calculates as a larger loss for the South due to 'reverse piracy' from the North by its use of seeds and medicines from biodiversity in the South (RAFI, 1994). In 1995, RAFI characterized biopiracy as a 'global pandemic' (RAFI, 1995). They argued that 'there are few places on earth where rural people are not facing biopirates who aim to extract their knowledge and resources' (ibid.). The Indian activist Vandana Shiva is central in NGO networks opposing multinational companies' activities within bioprospecting for developing food crops and drugs. In Biopiracy: The Plunder of Nature and Knowledge (Shiva, 1997) she compares present trends of bioprospecting, biotechnology and intellectual property rights with previous discovery, piracy and colonization.

The message of the biopiracy discourse can be summarized as vehement resistance to the commercial collection, development and patenting of

11. From 1999, ShamanBotanicals.com constitutes the main operating division of the company. 
modern medicines from biodiversity and traditional knowledge in the South. The advocates of this discourse emphasize questions of rights and equity for indigenous peoples, local peasants and healers. They do not believe in the provisions of satisfactory benefits to these groups from bioprospecting. The narratives may focus the attention on different stages in the bioprospecting process, but they all constitute examples in which bioprospecting and patenting inevitably end up as exploitation. Several narratives have been produced with specific examples of biopiracy. The bioprospecting proponents' success story of the 1991 INBio and Merck agreement has been met by a counter-narrative in which the benefits to Costa Rica are perceived as low, and which focuses on a lack of benefits for indigenous people (Kloppenburg and Rodriguez, 1992; Mooney, 2000).

The activity of Shaman Pharmaceuticals has also generated narratives within the biopiracy opponents' discourse. Sangre de Drago (genus Croton) is widely used as a healing agent for several purposes by indigenous peoples in rainforests in Latin America. It is being developed by Shaman for novel products. In the GRAIN newsletter, Reyes (1996) examines Shaman Pharmaceutical's reciprocity policy in the case of Sangre de Drago. She argues that the company provides questionable compensation for indigenous knowledge. RAFI and Cultural Survival Canada identify the bioprospecting companies as villains in a series of pamphlets entitled Bio-pirates:

While Shaman Pharmaceuticals has raised millions in the US capital market on the basis of its bioprospecting successes, the Quichua community of Jatún Molino in Eastern Ecuador, one of the communities where Shaman collected Sangre de Drago and the knowledge of how to use it, has received less than $\$ 3000$ from Shaman, much of this money being payment for the labour and services of community members. (RAFI and Cultural Survival Canada, 1997)

The biopiracy narrative about Sangre de Drago provides criticism of specific patents as well as of Shaman Pharmaceutical's relationship to large pharmaceutical transnationals, such as Eli Lilly (Reyes, 1996: 17).

The heroes in the biopiracy narratives consist of indigenous people, traditional healers, peasants and others who possess traditional knowledge of the medicinal properties of plants. In the proponents' discourse, bioprospectors are among the heroes, while in the biopiracy discourse bioprospectors are labelled biopirates and counted as villains. Other foreign participants in bioprospecting also belong to this group, particularly multinational companies - a category seen as representing the embodiment of global capitalism and its negative impacts. The use of strong metaphors is striking. An image of an unethical and even criminal activity is created by terms such as biopiracy, colonialism, plundering and exploitation. Local poor, and particularly indigenous people, are seen as victims.

Local perceptions and further effects of bioprospecting by Shaman Pharmaceuticals have been investigated in Tanzania (Svarstad, 2000; Svarstad, forthcoming). The field study reveals local perceptions of the biosprospecting phenomenon that are somewhat at odds with both narratives of biopiracy and those of the proponents of bioprospecting. Traditional healers tend to 
express ambivalence concerning their experiences with the company. Their self-image as local scientists has made them eager to be involved with bioprospecting in order to possibly obtain access to modern scientific knowledge with the aim of incorporating new knowledge of plant medicines within their practices. Contact between external bioprospectors and traditional healers also tends to raise the status and legitimacy of the latter in the local community. On the other hand, the traditional healers in the investigation expressed disappointment as to the feedback that they had received so far from Shaman Pharmaceuticals, as well as from other visits by Tanzanian bioprospectors. The field research has not, in effect, provided information from which it is appropriate to construct a narrative in accordance with either of the two discourses. Instead, the study illustrates the necessity for any intervention - by bioprospectors as well as solidarity groups - and the necessity for recognition of local contexts and social hierarchies and resource use strategies.

There are indeed striking differences in the two discourses' presentations of the practice of bioprospecting and the perceptions of major participants. However, both focus on the situation of the poor South in contrast to the rich North and, in particular, they express support for local and indigenous peoples. Furthermore, both are concerned at their core with the maintenance of biodiversity.

In the Tanzanian case, representatives from Shaman Pharmaceuticals described the experiences as a successful win-win example. However, local actors were disappointed about the extent of their gains, and the study shows that this was related to their lack of participation in real decisionmaking. On the other hand, most of the traditional healers in this case view bioprospecting as an opportunity to reach some of their objectives. Solidarity actions based on the biopiracy discourse try to stop the whole activity or necessary elements such as patenting. These campaigns make bioprospecting less attractive for the industry. Thus, local actors - the healers in the Tanzanian case - lose from the implications of the policy and regulatory environment that promotes bioprospecting.

\section{Climate Change}

Global climate change is at the forefront of debates on global environmental change because of its truly global nature and the pervasiveness of the interests of the carbon economy within the global economic system. The world's governments agreed at UNCED that potential climate change impacts are important enough to demand co-ordinated international action through the UN Framework Convention on Climate Change. But the development of this global environmental issue leads to climate change and its implications being illegible at other scales and hence ignoring the social mechanisms and processes by which adaptation may occur. The major 
discourses in this area (following Thompson and Rayner, 1998) promote the ideas of managerialism and profligacy. The managerial discourse evokes institutional failure and population growth as the causes of climate change and suggests international action as a solution. The profligacy discourse evokes over-consumption as the root cause of climate change and suggests that only tackling this fundamental issue will avert global catastrophe.

Managerial and profligacy arguments do not exist in isolation from the institutions and interests that promote them. Neither are they static. Thompson and Rayner (1998) argue that there has been a significant evolution in these discourses in the past decade. The voices clammering to be heard in the 1980s were primarily arguing their case in terms of the uncertain science of climate change. The major discourses in that decade can be labelled preventive and adaptive - 'something must be done' versus 'we can all adapt'. Of course these arguments continue to the present day but are now subsumed within emerging dominant and alternative narratives. In the 1990s, the major discourses surrounding climate change increasingly accepted climate change as reality and as a significant problem. O'Riordan and Jäger (1996) argue that this acceptance is the result both of scientific advance and of the institutionalization of the issue. ${ }^{12}$ The major discourses of managerialism and of profligacy differ in their interpretation of responsibility for the present level of enhanced greenhouse effect, equity and institutional response.

The managerial discourse dominates the climate change debate. Institutional and policy failure is here placed as the ultimate cause of the problem. Energy regulators have not adopted correct pricing policies for fossil fuels, and lack of understanding of the carbon sequestration role of sinks such as forests have led to their over-exploitation. On the basis of welfare economic analysis, an acceptable level of climate change can potentially be found which weighs the marginal cost of the impacts of climate change with the marginal cost of abating climate change (see, for example, Cline, 1992; Fankhauser 1995). This would require significant, and to date politically unacceptable, increased costs of the use of fossil fuel to reflect the true scarcity of a secure global climate.

The managerial discourse in climate change also has, however, elements of neo-Malthusian arguments. This rhetoric is bound up with the inevitability of numbers - projections of global population size, and particularly population growth in the developing world, coupled to projected increasing levels of consumption per capita in the developing world, ensure that population is a touchstone of concern for global policy-makers. These population arguments are outlined by Thompson and Rayner (1998) who analyse policy pronouncements in this area. They show that even if it is

12. The institutionalization of climate science is manifest in what Jasannoff and Wynne (1998) have called the 'standardization of science' in this area. 
accepted that responsibility for climate change is shared between the industrialized and the developing world, the onus for action on population lies at the door of the developing world. Further, the major impacts of climate change will be on poor developing countries because those countries lack the technology or resources to cope. These secondary consequences include large-scale international migration caused by population displacement as a result of sea level rise or drought, leading to the spectre of largescale immigration to wealthy Northern countries.

The managerial discourse draws its authority from science. It relies on the apparent scientific consensus suggesting that climate change is a reality - global climate change is a 'scientific certainty' and will not be avoided (Parry et al., 1998; Wigley et al., 1996). The world is therefore committed to adapting to a changed climate system in all its manifestations. This line of argument, based on global assessments such as the Intergovernmental Panel on Climate Change (IPCC), suggests that we should undertake precautionary action on climate change because the impacts are significant and differentiated. The solutions to the climate change problem are alluded to above - get the price of carbon right; rely on scientific advance to refine the understanding of the impacts of climate change and the costs of adaptation; and seek novel markets and property rights to provide a role for the private sector (Chichilinsky and Heal, 1998).

The profligacy discourse puts the blame for climate change squarely at the door of the industrialized world. It is here that the carbon economy has run riot, encouraging wasteful consumption patterns and indirectly causing land use changes. Further, it is the Northern industrialized countries that have undertaken historic land use changes and hence increased atmospheric concentrations of greenhouse gases, particularly in the nineteenth century (Adger and Brown, 1994). This discourse also draws its authority both from science and from a moral imperative. Proponents of this discourse, often centred around NGOs such as the Climate Action Network, highlight science within the remit of the IPCC, for example, which emphasizes irreversibility and plausible catastrophic surprises in the climate system. Similarly, the responsibility for causing climate change is portrayed as a moral argument. Researchers and Southern activists in the 1990s successfully highlighted the historical responsibility and 'natural debt' of industrialized countries in increasing atmospheric concentrations of greenhouse gases (for example, Agarwal and Narain, 1991; Hayes and Smith, 1993).

The justice issues of climate change are re-emerging in importance as the impacts of climate change become more certain (Adger, 2001). The solutions to climate change under this discourse are therefore diametrically opposed to the managerial discourse. Climate NGO activists have been vocal in rejecting, for example, the implementation of the moves towards carbon trading inherent in the Kyoto Protocol of the Climate Change Convention, arguing that planting trees in developing countries to offset emissions in the profligate industrialized countries is an abdication of responsibility (see 
Brown and Adger, 1994). They call for preventative action and, in effect, a new economic order (Newell, 2000). The use of the discourses within international negotiations clearly reflects the multi-level nature of the political ecology of climate change. Lobbies are created, break up and re-form within the climate change arena through appeal to these discourses. The long term impacts of climate change, particularly on the viability of low-lying small island states, for example, are presented as an intergenerational issue, with vociferous collective lobbying by the Association of Small Island States and others.

These are highly stylized accounts, but nonetheless reflect the two major discourses (managerial and profligacy) within the debate on climate change. Both major discourses have in common their reliance on scientific assessment at global or continental scales. They do not inform, nor are they informed by, the social processes of adaptation. They are also exhibited in the institutions surrounding the Climate Change Convention. The discourses surrounding climate change are implicit in outcomes of international agreements. The Conferences of the Parties to the Climate Change Convention, beginning with Buenos Aires in 1998, have now directly linked adaptation to mitigation in terms of the costs to society. The greatest single equity issue, and the spectre which overshadows all debates on what to do about climate change, is that of the differential impacts of climate change and the highly skewed costs of adaptation at global and local scales. The vulnerability of societies to climate impacts and the costs of adaptation therefore demonstrate some pertinent debates in social equity because of the long-term and uncertain nature of impacts.

Much of the science appealed to by both discourses is summarized in the reports of the Intergovernmental Panel on Climate Change (IPCC). ${ }^{13}$ But this global scale analysis, based on the belief that intervention and global management of the problem are necessary, does not take into account the processes of adaptation. The mechanisms by which adaptation to climate change and variability are promoted are, in reality, related to the political economy of resource use. Diverse and conflicting impacts on adaptive capacity can be observed at the same time. Changes in resource use in coastal areas can enhance or reduce adaptive capacity. A study in Vietnam, for example, demonstrates how the restructuring of ownership and control of coastal resources throughout Vietnam's coastal provinces and the reduction of collective action in these areas results in an increasingly hazardous environment for coastal residents and hence exacerbates vulnerability to climate change (Adger, 1999). At the same time, rehabilitation of coastal mangroves to protect the coast against present-day storm impacts is enhancing adaptive capacity in these areas. Thus vulnerability and adaptive capacity are determined by institutions and are a function of social capital.

13. The report of the Third Assessment of the IPCC is outlined in summaries for policymakers at http://www.ipcc.ch/ 
We argue that vulnerability and adaptation are not legible to either the dominant managerial discourse or the alternative populist discourse, both of which portray societies as fragile and disempowered in the face of global climate change. The dominant managerial discourse portrays climate change as a monolithic non-differentiated phenomenon and resource dependent communities as hapless victims of impacts. The evidence for impacts of climate change is mounting, as outlined by the Third Assessment Report of the IPCC in 2001, yet local adaptation to global changes remains opaque to the global discourses.

\section{COMPARING DISCOURSES}

We now seek to draw out parallels and major differences in the discourses of the four environmental issues. Through a comparison of the messages, narrative structures and role of external interventions perceived in the discourses, we have identified two clusters of main discourses. These are a set of Global Environmental Management (GEM) discourses which are dominating in terms of influence on environmental policies and a set of Populist discourses which constitute reactions against the former and also have considerable policy impacts. The major arguments are summarized and stylized in Table 1. Both clusters perceive the existence of global environmental problems. Most of the populist discourses tend to be more concerned with negative local impacts of interventions by external actors involved with conservation and the use of natural resources. The causes and cures implied by the two clusters are diametrically opposed. A third set of heterodox ideas and denial claims are discussed below.

In each of the environmental areas discussed above, the dominant discourse identified claims the existence of a global environmental crisis in the respective areas. This is backed by a set of international scientific analyses such as the Global Biodiversity Assessment, the World Atlas on Desertification and the publications of the Intergovernmental Panel on Climate Change. The global environmental crises implied in GEM discourses require global solutions. The discourses are therefore top-down, interventionist and technocentrist in that solutions to the alleged global environmental problems can and should be devised. The solutions are defined at the global level. Hence, international action is necessary. This action should be co-ordinated by multi-lateral agencies and regulatory frameworks. When the problems are presented as the outcome of interactions between countries (which are rational actors motivated by national self-interest), then global action is inevitably interpreted as action by a set of state actors (Kaul et al., 1999; Rowlands, 1995; Sandler, 1997). Although the emphasis in GEM discourses is on the role of states, it is essentially neo-liberal in espousing marketoriented solutions. Elliot (1999: 1) suggests that GEM discourses are, in essence, based on neo-liberal values: 'International political responses to the 

Table 1. Characterizing Managerial and Populist Discourses in Global
Environmental Issues

\begin{tabular}{|c|c|c|}
\hline & $\begin{array}{l}\text { Global Environmental Management } \\
\text { (GEM) discourses }\end{array}$ & Populist discourses \\
\hline Deforestation & $\begin{array}{l}\text { Neo-Malthusian discourse on } \\
\text { increasing population and } \\
\text { agricultural conversion in } \\
\text { developing countries with } \\
\text { slash-and-burn farmers being the } \\
\text { primary villains. }\end{array}$ & $\begin{array}{l}\text { Populist discourse believes } \\
\text { deforestation to be a significant } \\
\text { issue caused by the marginalization } \\
\text { of rural poor and external forces of } \\
\text { globalization such as Northern } \\
\text { consumption of timber products. }\end{array}$ \\
\hline Desertification & $\begin{array}{l}\text { Neo-Malthusian discourse suggests } \\
\text { that local resource users in } \\
\text { drylands are degrading the } \\
\text { ecosystems on which they depend. } \\
\text { Only international action and strict } \\
\text { regulation can prevent further } \\
\text { desertification. }\end{array}$ & $\begin{array}{l}\text { Populist discourse accepts the } \\
\text { evidence that desertification is } \\
\text { important but suggests that it is the } \\
\text { inevitable consequence of historic } \\
\text { marginalization of pastoralists and } \\
\text { smallholders in both the colonial } \\
\text { and post-colonial periods. }\end{array}$ \\
\hline Biodiversity Use & $\begin{array}{l}\text { Bioprospecting discourse promotes } \\
\text { sustainable utilization of } \\
\text { biodiversity as the solution to an } \\
\text { impending extinction crisis. This } \\
\text { solution can be promoted through } \\
\text { international co-operation and } \\
\text { institutions. }\end{array}$ & $\begin{array}{l}\text { Biopiracy discourse portrays an } \\
\text { extinction crisis promoted by the } \\
\text { institutions and interests of } \\
\text { capitalism that threaten both } \\
\text { cultural and biological diversity. }\end{array}$ \\
\hline Climate Change & $\begin{array}{l}\text { Managerial discourse on the } \\
\text { compelling science of climate } \\
\text { change requiring new markets for } \\
\text { carbon and global institutions. }\end{array}$ & $\begin{array}{l}\text { Profligacy discourse also accepts } \\
\text { climate change as a major problem } \\
\text { and as the key symptom in the } \\
\text { crisis of global over-consumption } \\
\text { espoused by capitalism. }\end{array}$ \\
\hline
\end{tabular}

globalised challenges of environmental change have been accommodated within and informed by neo-liberal values and modalities. This neo-liberal orthodoxy has been confirmed by the dominant analytical and theoretical responses to the environmental agenda'.

Thus, the institutions generated from these processes advocate solutions through technological and resource transfers. This GEM discourse resonates with concepts such as ecological modernization which Hajer (1995) argues is a hegemonic discourse on Northern environmental issues. The existence of 'win-win' policies and institutions is a key concept of the managerial discourses. In diverse areas, from climate change to debt-fornature swaps, this rhetoric is utilized, often tied to technological solutions and even North-South technology transfers. Such win-win solutions are institutionalized through the Global Environment Facility, for example, which promotes projects for their global environmental benefits (see Rich, 1994). The managerial discourse is based on development optimism and faith in the opportunities for local benefits in poor countries through exchanges with private and public parties from industrialized countries. 
By contrast, the populist discourses identified in Table 1 also encompass a belief in impending crises, but their narratives are based on the perpetrators being global capitalism and the victims being the local resource users who are the villains of the managerial discourse. International economic relations including international development assistance are portrayed as negative interventions and as neo-colonialism rather than as offering possibilities for trade, income and conservation. Local and traditional knowledge is seen as a provider of sustainable practices, and local people will therefore be better off when left alone. The philosophical roots of the populist discourses on development issues can be traced back to self-reliance advocacy derived from the dependency schools of the 1970s and 1980s and beyond to the writings of Chayanov and others. In the 1990s, a trend of post-structuralist writing within this discourse emerged in which development and foreign intervention are categorically rejected (Peet and Watts, 1996; Yapa, 1996).

\section{Messages and Narrative Structures in Managerial and Populist Discourses}

Here we compare the GEM and populist discourses with respect to their messages, narrative structures (that is, their cast of heroes, villains and victims), and their views of external intervention and solutions. Two clear messages are discernible in both the GEM and populist discourses concerning the environmental issues outlined above, and these are illustrated and expressed through narratives. The first common message presents the environmental problem as a crisis (see Roe, 1991, 1995 and 1999), associated with irreversible and systemic changes to the environment. Irreversible change is evident in both the GEM and populist discourses in each of the four areas.

The second common message in the GEM and populist discourses is that the changes to the physical environment will inevitably have severe social, economic and political ramifications. Climate change, desertification and deforestation discourses each have associated narratives which feature 'environmental refugees' resulting from abrupt environmental changes. ${ }^{14}$ Narratives of biodiversity loss mention the potential medicines currently undiscovered which might be lost forever. In each case, the implication is that humankind, not just the biosphere, will suffer as a result of these environmental problems.

Comparison of the narrative structures associated with the dominant discourses in the four areas is more complex, and the GEM and populist discourses differ markedly. There are common themes in the GEM discourses

14. See Homer-Dixon (1994) and critiques by Hartmann (1998) and Barnett $(2000,2001)$ for example. 
on deforestation, desertification and climate change. Local farmers, peasants and landless poor are portrayed as villains in each. This is particularly the case in the neo-Malthusian discourses on desertification and deforestation. Local farmers and land users are seen as the principal causal agents of these problems. In the climate change GEM discourse poor farmers of rice and in frontier agricultural areas, although being low energy consumers, are portrayed as villains as their activities cause the emissions of greenhouse gases through land use change and hence are argued to contribute significantly to the global problem.

In the GEM discourses, local people are also victims - they may undertake their environmentally damaging activity through no fault of their own and are also the victims of the problem itself. Often this is expressed through narratives which describe 'vicious cycles' of poverty and environmental degradation. These are prevalent in desertification and deforestation discourses. The heroes according to these discourses would be scientists, national civil servants, aid bureaucrats and others who have understood the vicious cycles and who see the need for urgent action. These heroes are, evidently, also the main promoters of the GEM discourses within deforestation and desertification. The GEM discourse concerning bioprospecting is also based on the same understanding of local people as both villains and victims concerning biodiversity losses. In the narratives concerning bioprospecting, however, there are portraits of local people and bioprospectors constituting heroes in harmonic exchanges.

Populist discourses in each area portray global capitalism, transnational corporations and colonial powers as villains. Thus, logging companies, ranchers and plantation owners are the main causal agents of deforestation; the uneven terms of trade force Sahelian countries to produce cotton and groundnuts leading to soil depletion and desertification; and pharmaceutical companies are biopirates. The discourses on climate change and deforestation, and to an extent those on biodiversity and desertification, also identify the Northern consumers as villains - it is the profligacy of the North which causes the global environmental problem, while the poor of the South are both victims and heroes.

\section{Interactions between Discourses and Policy Outcomes}

Accepted wisdom, knowledge and scientific research in each of the areas are used as justifications for policies and interventions. The GEM and populist discourses in each of the four areas view the role of external intervention quite differently. Populist discourses in general see external intervention as part of the problem itself. This is particularly the case for the deforestation, desertification and biopiracy populist discourses. In these areas, penetration by external actors has caused or exacerbated the environmental problems. The populist discourses within each area see the local community and the 
indigenous populations as the appropriate focus for action. Populist discourses emphasize rights, justice, self-determination and empowerment as the means by which environmental problems can be overcome in the long term.

On the other hand, the GEM discourses in each of the four areas view external intervention as a key feature of solutions to the environmental problems. We can discern four types of external intervention allied with the GEM discourse. The first type of intervention involves technology or knowledge transfers. These transfers are evident in GEM solutions to desertification and climate change, and least explicit in the case of deforestation. The second type of intervention concerns financial transfers or compensation payments and is common across all issues. Financial payments are encouraged, for example, for the conservation of forests and biodiversity, to support the adoption of 'clean technologies' and to provide incentives for farmers to adopt soil conservation practices. Institutional forms of the market mechanisms include the Clean Development Mechanism of the Climate Change Convention and 'debt-for-nature swaps' in conservation.

The third type of intervention espoused by proponents of the GEM discourses relates to financial incentives by calling for the strengthening and creation of markets and valuing or pricing resources correctly in order to bring about changes in resource management. This type of intervention is particularly associated with the deforestation, biodiversity and climate change discourses, with efforts being made to create markets and set 'correct' prices to account for externalities (see Pearce, 1995 for a review). This market creation intervention is less prominent in desertification discourses. The fourth type of intervention is shared by all four areas and is central to the GEM view. This is the perception that international agreements and regulation are central to mitigating global environmental problems. In the areas of climate change, biodiversity and desertification, action is taken through the UN Conventions, and in the area of deforestation it takes place through institutions such as the UN's Intergovernmental Forum on Forests and the International Tropical Timber Organization. These conventions and institutions represent the outcome of the dominance of this discourse, but at the same time are continually reinforcing the hegemony of the GEM view. No discussion of biodiversity loss, climate change, or desertification, even at the local level, can be made without reference to these global imperatives.

In our discussion, we have emphasized the differences between GEM and populist discourses. It may also be argued, however, that these discourses sometimes present hardly distinguishable points on a continuum, and that they constantly overlap and redefine each other. The discourses cannot be seen as constants. The populist discourse on deforestation, for example, makes in-roads into the GEM discourse at the margins in a number of ways. One example is the initiative on 'Underlying causes of deforestation and forest degradation' which enabled NGO and community-based organizations 
to input into intergovernmental negotiations on forest policy. ${ }^{15}$ The initiative's statements identify lack of secure tenure, lack of indigenous peoples' rights, privatization of forests, and lack of empowerment and participation of local communities in decisions over forest management as key causal factors in deforestation. In this respect, it is firmly within the populist discourse. The initiative has importantly sought to shift the emphasis away from deforestation being an issue only in tropical countries to focus on forest degradation in rich countries of the North. But in 'opting into' the Intergovernmental Forum on Forests process, it seeks to influence the policy agenda prescribed by the GEM deforestation discourse.

The populist discourse on deforestation has also promoted communitybased approaches to conservation and forest management. This can be seen in the emphasis of bi-lateral and multi-lateral conservation and development projects on what can loosely be termed community-based approaches to forest management. Large international conservation NGOs have also adopted the narratives and rhetoric of the populist discourses in promoting people-orientated conservation and development projects and in forming alliances with indigenous peoples' organizations (Brown and Rosendo, 2000; Jeanrenaud, 1998).

Similar trends can be observed in debates surrounding desertification where populist focuses on community-based approaches have been co-opted by state and donor policies. This has resulted in the well-known Gestion de Terroir approach advocated throughout the West African Sahel as a remedy against desertification. In the same vein, all francophone Sahelian states are currently implementing decentralization reforms, encouraged by structural adjustment programmes. One important aim of these reforms is to improve natural resource management through more community participation. The International Convention to Combat Desertification also has a major focus on decentralization. It remains to be seen, however, whether these initiatives will lead to the devolution of real decision-making power to the grassroots level or if the result will merely be a deconcentration of state power (see Benjaminsen, 1997b, 2000; Ribot, 1999; Turner, 1999).

\section{Heterodox Ideas and Denial Claims}

In each of the areas of global environmental change examined, there are a set of heterodox ideas and even claims of denial concerning the existence or

15. These policy deliberations took place under the Intergovernmental Panel on Forests (which later became the Intergovernmental Forum on Forests), established post-UNCED under the auspices of the UN Commission on Sustainable Development to establish a dialogue and process to seek international consensus on forest management. The recommendations of the Intergovernmental Forum were presented to the eighth session of the UN Commission on Sustainable Development in April 2000. 
gravity of the environmental issue. These denial claims are strongest within the climate change and desertification debates where vested interests seek to negate knowledge through pointing to apparent inconsistencies in empirical evidence or making explicit the interests in the dominant discourses. On climate change, we argue that there is an established denial discourse that is somewhat influential - a voluble minority view argues either that global warming is not scientifically provable or that it is not a serious issue.

This is a minority view, but has been influential in the geo-politics of climate change. The denial discourse argues that climate change is not a problem. It suggests that adaptation to climate change will occur naturally as has been the case in the evolution of societies over the centuries (Burroughs, 1997). This line of reasoning utilizes two other observations to argue that the problem of global climate change is inconsequential. First, the science of observed climate change is uncertain and this uncertainty points to postponement of tackling the issue as the best use of scarce resources in the present day. Beckerman (1995) for example, argues that adaptation to climate change has occurred in the past through human migration. Referring to voluntary migration to take advantage of a pleasant climate, which can be observed for example in the southern 'sunbelt' states of the US, he points out that 'global warming could mean that future generations would not have to go to all the trouble [of migrating]' (Beckerman, 1995: 91). Beckerman also argues that postponing precautionary action does not jeopardize the ability to cope with future potential rates of warming: delaying action for a decade means that 'we would all have plenty of time to change into lighter shirts' (Beckerman, 1995: 100). In this line of reasoning potential rates of future climate change pose no significant problems. Second, significant public policy action to reduce the causes of climate change is expensive. Hence allocating resources to mitigate climate change, following this argument, is inequitable to those who are in need of 'development' today. These perceptions together lead to the conclusion that even if there is some cause for concern, any action should be postponed until scientific uncertainty is reduced (Manne and Richels, 1992).

Within desertification, there is also a denial discourse. It has a strong position among researchers, but so far only a marginal policy impact. This discourse argues that human action by farmers and pastoralists is not causing widespread desertification or land degradation in drylands and that if there are any long-term negative trends they would primarily be caused by decline in rainfall. However, long-term trends in rainfall are debatable, varying widely by region and timescale chosen.

In a rather different manner within the deforestation debate, there is an emerging alternative and critical view questioning whether deforestation is a global problem by claiming, for example, that the rates presented by deforestation orthodoxy are exaggerated. Some of these analyses are undertaken to expose the dominant discourses as obscuring the complex interactions between people and their environments (Fairhead and Leach, 1998) 
while others seek to discredit the idea of a global forest crisis (Stott, 1999). While deforestation denial views have clear populist influences and have rural people in the South as their heroes, denial of the existence of global climate change tends to be promoted by Northern economic interests. In biodiversity there are attempts to fundamentally refute the losses of species, but the conservation politics linked to these debates are largely a matter for the domestic agendas of particular countries, such as the 'wise use' lobby in the US (see, for example, Lomborg, 1998; Stott, 1999). Thus the dichotomy which we highlight, of managerial and populist discourses, is itself highly stylized. Alternative views, sometimes specifically attempting to show the poverty of monolithic discourses, also compete to be heard in this important sphere.

\section{CONCLUSIONS}

This article has examined four central apparently-global environmental issues and has identified within them two competing discourses. In each of the areas of deforestation, desertification, biodiversity and climate change, the dominance of Global Environmental Management in debates on these issues is evident. They dominate what Brosius (1999) has termed the 'globalised political space' of the environmental arena. This cluster of discourses dominates the institutions and policies surrounding international agreements and global blueprints and espouses global co-ordinated action and the creation of novel markets and property rights to solve the crises of global environmental change. Each of the areas also has a competing populist discourse, often constituted through non-governmental organizations and in alliance with particular state or sectoral interest groups. We define these discourses as populist because of the positive way they portray acts of local people, and their negative portrayal of foreign interventions.

Of course this dichotomy is highly stylized. There are many alternative voices in the arenas of global environmental change, and discourses are constantly being reformulated. For instance, attempts often take place to establish authority through interpretation of the latest scientific analysis. We also point to a trend in global environmental change of inroads being made by the populist discourses into the territory of global management, through the enrolment of peripheral actors and alliances with the dominant institutions. Denial claims concerning the existence or gravity of the environmental problem can be found in all the areas. These minority narratives have, with the exception of the climate change area, not been successful in influencing policy debates to date.

The convergence of some managerial and populist discourses may be seen in some respects as the inevitable consequence of their commonalities in how they view the world and society. In many, but not all cases, the dominant ideas within global environmental change are based on a belief that we are 
on the verge of global catastrophe, placing strain on a fragile earth and risking irreversible change. At the same time most of the discourses we have examined also view global society, and societies in the developing world in particular as equally fragile, and these countries as hapless victims of globalization and change.

We have provided examples in each of the four areas showing the shortcomings of the identified discourses to provide satisfactory frameworks for understanding problems and concomitant solutions and actions in specific cases. Thus, a major conclusion from our investigation is to point to striking discrepancies between discursive simplifications and the diversity of situations within local contexts. These local contexts are largely illegible through the lenses of the two main environmental discourses discussed in this article. Such illegibility and simplification of reality are linked to attempts at legibility, standardization and simplification articulated in the context of state modernization by Scott (1998). The resulting simplified designs for social organization and environmental management can be seen as logical consequences of the broader discourses we discuss here.

This analysis is important not for the typology of discourses or identification of the modernist rhetoric and hegemonic myths of nature and society underpinning them. Rather we have sought to show that adopting the language and rhetoric of Global Environmental Management constrains the solutions proposed for these issues. These technocratic solutions do not necessarily reflect ecological realities of the human utilization of the environment. By this means discourse analysis can, we argue, contribute to a political ecology sensitive to the political construction and use of scientific knowledge and multi-level nature of interactions between institutions and environmental change.

\section{Acknowledgements}

The authors have contributed equally to the article and are listed in alphabetic order: no seniority in authorship is assigned. We thank the Research Council of Norway and The British Council for funding this research. We also thank Jon Barnett of the MacMillan Brown Centre for Pacific Studies, University of Canterbury, Dr Strangelove, Andrew Jordan and colleagues in Norwich, Ås and Oslo, and two anonymous referees of this journal, for constructive comments. Neil Adger and Katrina Brown thank colleagues at the Department of Geography, University of Canterbury, New Zealand for support while writing the article. The final version remains our own responsibility.

\section{REFERENCES}

Adger, W. N. (1999) 'Social Vulnerability to Climate Change and Extremes in Coastal Vietnam', World Development 27(2): 249-69.

Adger, W. N. (2001) 'Scales of Governance and Environmental Justice for Adaptation and Mitigation of Climate Change', Journal of International Development 13(5). 
Adger, W. N. and K. Brown (1994) Land Use and the Causes of Global Warming. Chichester: Wiley.

Agarwal, A. and S. Narain (1991) Global Warming in an Unequal World: A Case of Environmental Colonialism. New Delhi: Centre for Science and Environment.

Allen, J. and D. Barnes (1985) 'The Causes of Deforestation in Developing Countries', Annals of the Association of American Geographers 75(2): 163-84.

Angelsen, A. and D. Kaimowitz (1999) 'Rethinking the Causes of Deforestation: Lessons from Economic Models', World Bank Research Observer 14(1): 73-98.

Aubreville, A. (1949) Climats, Forêts et Désertification de l'Afrique Tropicale. Paris: Société d'Editions Géographiques, Maritimes et Coloniales.

Baker, J. T. et al. (1995) 'Natural Product Drug Discovery and Development: New Perspectives on International Collaboration', Journal of Natural Products - Lloydia 58(9): 1325-57.

Barnett, J. (2000) 'Destabilising the Environment-Conflict Thesis', Review of International Studies 26(2): 271-88.

Barnett, J. (2001) The Meaning of Environmental Security: Ecological Politics and Policy in the Environmental Security Era. London: Zed Books.

Bawa, K. S. and S. Dayanandan (1997) 'Socioeconomic Factors and Tropical Deforestation', Nature 386(6625): 562-63.

Beckerman, W. (1995) Small is Stupid: Or Blowing the Whistle on the Greens. London: Duckworth.

Behnke, R. H. and I. Scoones (1993) 'Rethinking Range Ecology: Implications for Rangeland Management in Africa', in R. H. Behnke, I. Scoones and C. Kerven (eds) Range Ecology at Disequilibrium: New Models of Natural Variability and Pastoral Adaptation in African Savannas. pp. 1-30. London: Overseas Development Institute and IIED.

Benjaminsen, T. A. (1993) 'Fuelwood and Desertification: Sahel Orthodoxies Discussed on the Basis of Field Data from the Gourma Region in Mali', Geoforum 24(4): 397-409.

Benjaminsen, T. A. (1996) 'Bois-énergie, Déboisement et Sécheresse au Sahel: Le Cas du Gourma Malien', Sécheresse 7(3): 179-85.

Benjaminsen, T. A. (1997a) 'Is there a Fuelwood Crisis in Rural Mali'? GeoJournal 43(2): 163-74.

Benjaminsen, T. A. (1997b) 'Natural Resource Management, Paradigm Shifts and the Decentralisation Reform in Mali', Human Ecology 25(1): 121-43.

Benjaminsen, T. A. (2000) 'Conservation in the Sahel: People and Policies in Mali (1900-1998)', in R. Schroeder and V. Broch-Due (eds) Producing Nature and Poverty in Africa, pp. 94-108. Uppsala: Nordic Africa Institute.

Benjaminsen, T. A. (2001a) 'The Malian Cotton Zone: Economic Success but Environmental Failure?' in T. A. Benjaminsen and Chr. Lund (eds) Politics, Property and Production in the West African Sahel: Understanding Natural Resources Management. Uppsala: Nordic Africa Institute (in press).

Benjaminsen, T. A. (2001b) 'The Population-Agriculture-Environment Nexus in the Malian Cotton Zone', Global Environmental Change 11(4): in press.

Berger, A. A. (1997) Narratives in Popular Culture, Media, and Everyday Life. Thousand Oaks, CA: Sage.

Best, J. (1989) Images of Issues: Typifying Contemporary Social Problems. New York: Aldine de Gruyter.

Bilsborrow, R. E. and M. Geores (1994) 'Population, Land Use and the Environment in Developing Countries: What Can we Learn from Cross-national Data?', in K. Brown and D. W. Pearce (eds) The Causes of Tropical Deforestation. pp. 106-33, London: UCL Press.

Blaikie, P. and H. Brookfield (1987) Land Degradation and Society. London: Methuen.

Bovill, E. W. (1921) 'The Encroachment of the Sahara on the Sudan', Journal of the African Society 20: 174-85, 259-69.

Bromley D. W. (1998) 'Deforestation: Institutional Causes and Solutions', in M. Palo and J. Uusivuori (eds) World Forests, Society and Environment, pp. 95-101. Dordrecht: Kluwer.

Brosius, J. P. (1999) 'Anthropological Engagements with Environmentalism', Current Anthropology 40(3): 277-309. 
Brown, K. and W. N. Adger (1994) 'Economic and Political Feasibility of International Carbon Offsets', Forest Ecology and Management 68(2): 217-29.

Brown, K. and F. Ekoko (2001) 'Forest Encounters: Synergy among Agents of Forest Change in Southern Cameroon', Society and Natural Resources 14(4): 269-90.

Brown, K. and S. Lapuyade (2001) 'A Livelihood from the Forest: Gendered Visions of Social, Economic and Environmental Change in Southern Cameroon', Journal of International Development 13 (in press).

Brown, K. and M. Muchagata (1999) 'Sustainability of Forest Frontier Farming at the Forest Fringe'. Norwich: School of Development Studies, University of East Anglia.

Brown, K. and D. W. Pearce (eds) (1994) The Causes of Tropical Deforestation. London: UCL Press.

Brown, K. and S. Rosendo (2000) 'Environmentalists, Rubber Tappers and Empowerment: The Politics and Economics of Extractive Reserves', Development and Change 31(1): 201-27.

Bryant, D., D. Nielsen and L. Tangley (1997) The Last Frontier Forests: Ecosystems and Economies on the Edge. Washington, DC: World Resources Institute.

Bryant, R. L. and S. Bailey (1997) Third World Political Ecology. London: Routledge.

Burroughs, W. J. (1997) Does the Weather Really Matter? The Social Implications of Climate Change. Cambridge: Cambridge University Press.

Carr, S. and R. Mpande (1996) 'Does the Definition of the Issue Matter? NGO Influence and the International Convention to Combat Desertification in Africa', Journal of Commonwealth and Comparative Politics 34(1): 143-66.

Chichilinsky, G. and G. Heal (1998) 'Economic Returns from the Biosphere', Nature 391(6668): 629-30.

Cline, W. R. (1992) The Economics of Global Warming. Washington, DC: Institute for International Economics.

Colchester, M. and L. Lohmann (eds) (1993) The Struggle for Land and the Fate of the Forests. London: Zed Books.

Conkin, B. A. and L. R. Graham (1995) 'The Shifting Middle Ground: Amazonian Indians and Ecopolitics', American Anthropologist 97: 695-710.

Dioné, J. (1989) 'Informing Food Security Policy in Mali: Interactions between Technology, Institutions and Market Reforms'. PhD Thesis. Massachussetts State University, Boston.

Dryzek, J. S. (1997) The Politics of the Earth: Environmental Discourses. Oxford: Oxford University Press.

Eisner, T. (1989) 'Prospecting for Nature's Chemical Riches', Issues in Science and Technology 6(2): 31-4.

Eisner, T. (1991) 'Chemical Prospecting: A Proposal for Action', in F. Bormann and R. Kellert (eds) Ecology, Economics, and Ethics: The Broken Circle, pp. 196-202. New Haven, CT: Yale University Press.

Elliot, L. (1999) 'The Global Politics of the Environment'. Paper presented at 'The New Agenda for International Relations: Ten Years After the Wall', University of East Anglia, Norwich (9-10 September).

Fairhead, J. and M. Leach (1998) Reframing Deforestation. Global Analyses and Local Realities: Studies in West Africa. London: Routledge.

Fankhauser, S. (1995) Valuing Climate Change: The Economics of the Greenhouse. London: Earthscan.

Ferguson, J. (1990) The Anti-politics Machine: 'Development', Depoliticisation and Bureaucratic Power in Lesotho. Cambridge: Cambridge University Press.

Foucault, M. (1979) Discipline and Punish: The Birth of the Prison. Harmondsworth: Penguin. Foucault, M. (1984) The History of Sexuality. Harmondsworth: Penguin.

Foucault, M. (1991) 'Politics and the Study of Discourse', in G. Burchell et al. (eds) The Foucault Effect: Studies in Governmentality, pp. 53-72. London: Harvester Wheatsheaf.

Goldman, M. (1998) 'The Political Resurgence of the Commons', in M. Goldman (ed.) Privatising Nature: Political Struggles for the Global Commons, pp. 1-19. New Brunswick, NJ: Rutgers University Press. 
Grillo, R. and J. Stirratt (1997) (eds) Discourses of Development: Anthropological Perspectives. Oxford: Berg.

Hajer, M. A. (1995) The Politics of Environmental Discourse: Ecological Modernisation and the Policy Process. Oxford: Clarendon.

Hannigan, J. A. (1995) Environmental Sociology. London: Routledge.

Hartmann, B. (1998) 'Population, Environment and Security: A New Trinity', Environment and Urbanization 10(2): 113-27.

Hayes, P. and K. Smith (eds) (1993) The Global Greenhouse Regime: Who Pays? London: Earthscan.

Helldén, U. (1991) 'Desertification: Time for an Assessment?' Ambio 20(8): 372-83.

Homer-Dixon, T. F. (1994) 'Environmental Scarcities and Violent Conflict', International Security 19(1): 5-40.

IUCN/UNEP/WWF (1991) Caring for the Earth. Gland, Switzerland: IUCN.

Jassannoff, S. and B. Wynne (1998) 'Science and Decision-making', in S. Rayner and E. Malone (eds) Human Choice and Climate Change. Vol 1 The Societal Framework, pp. 1-87. Washington, DC: Batelle Press.

Jeanrenaud, S. (1998) 'Can the Leopard Change its Spots? Exploring People-Centred Conservation in WWF'. PhD Thesis, School of Development Studies, University of East Anglia, Norwich, UK.

Kaoneka, A. R. S. (1998) 'African Forests, Societies and Environments', in M. Palo and J. Uusivuori (eds) World Forests, Society and Environment, pp. 139-45. Dordrecht: Kluwer.

ten Kate, K. (1995) Biopiracy or Green Petroleum? Expectations and Best Practice in Bioprospecting. London: Overseas Development Administration.

Kaul, I., I. Grunberg and M. A. Stern (1999) Global Public Goods: International Co-operation in the 21st Century. Oxford: Oxford University Press.

Keeley, J. and I. Scoones (2000) 'Knowledge, Power and Politics: The Environmental Policymaking Process in Ethiopia', Journal of Modern African Studies 38(1): 89-120.

Kloppenburg, J. Jr. and S. Rodriquez (1992) 'Conservationist or Corsairs?', Seedling 9(2/3): $12-17$.

Lamprey, H. (1975) 'Report on the Desert Encroachment Reconnaissance in Northern Sudan: 21 October to 10 November, 1975', reprinted in Desertification Control Bulletin 11(17): 1-7.

Lappé, F., M. J. Collins and P. Rosset (1998) World Hunger: Twelve Myths. London: Earthscan.

Leach, M. and R. Mearns (eds) (1996) The Lie of the Land: Challenging Received Wisdom on the African Environment. Oxford: James Currey.

Litfin, K. T. (1994) Ozone Discourses: Science and Politics in Global Environmental Cooperation. New York: Columbia University Press.

Lomborg, B. (1998) Verdens Sande Tilstand. Copenhagen: Centrum.

Mabbutt, J. A. (1984) 'A New Global Assessment of the Status and Trends of Desertification', Environmental Conservation 11(2): 103-13.

Manne, A. and R. Richels (1992) Buying Greenhouse Insurance. Cambridge, MA: MIT Press.

Marglin, F. A. and S. A. Marglin (eds.) (1990) Dominating Knowledge: Development, Culture, and Resistance. Oxford: Clarendon.

Mateo, N. (2000) 'Bioprospecting and Conservation in Costa Rica', in H. Svarstad and S. Dillion (eds) Responding to Bioprospecting: From Biodiversity in the South to Medicines in the North, pp. 45-55. Oslo: Spartacus.

Mooney, P. (2000) 'Why we call it Biopiracy', in H. Svarstad and S. Dillion (eds) Responding to Bioprospecting: From Biodiversity in the South to Medicines in the North, pp. 37-44. Oslo: Spartacus.

Moran, K. (1997) 'Returning Benefits from Ethnobotanical Drug Discovery to Native Communities', in F. Grifo and J. Rosenthal (eds) Biodiversity and Human Health, pp. 243-67. Washington, DC: Island Press.

Mortimore, M. (1989) Adapting to Drought: Farmers, Famines and Desertification in West Africa. Cambridge: Cambridge University Press. 
Mortimore, M. (1998) Roots in the African Dust: Sustaining the Drylands. Cambridge: Cambridge University Press.

Mugabe, J., C. V. Barber, G. Henne, L. Glowka and A. La Viña (1997) 'Managing Access to Genetic Resources', in J. Mugabe et al. (eds) Access to Genetic Resources: Strategies for Sharing Benefits, pp. 5-32. Nairobi: ACTS Press.

Myers, N. (1979) The Sinking Ark: A New Look at the Problem of Disappearing Species. New York: Norton.

Myers, N. (1984) The Primary Source: Tropical Forests and Our Future. New York: Norton.

Myers, N. (1994) 'Tropical Deforestation: Rates and Patterns', in K. Brown and D. W. Pearce (eds) The Causes of Tropical Deforestation, pp. 27-40. London: UCL Press.

Newell, P. (2000) Climate for Change: Non-State Actors and the Global Politics of the Greenhouse. Cambridge: Cambridge University Press.

Oba, G., N. Chr. Stenseth and W. Lusigi (2000) 'New Perspectives on Sustainable Grazing Management in Arid Zones of Sub-Saharan Africa', BioScience 50(1): 35-51.

O'Riordan, T. (1983) Environmentalism (2nd edn.). London: Pion.

O'Riordan, T. and J. Jäger (eds) (1996) Politics of Climate Change: A European Perspective. London: Routledge.

Palo, M. (1994) 'Population and Deforestation', in K. Brown and D. W. Pearce (eds) The Causes of Tropical Deforestation, pp. 42-56. London: UCL Press.

Parry, M., N. Arnell, M. Hulme, R. Nicholls and M. Livermore (1998) 'Adapting to the Inevitable', Nature 395(6704): 741.

Pearce, D. W. (1995) 'New Directions for Financing Global Environmental Change', Global Environmental Change 5(1): 27-40.

Peet, R. and M. Watts (1996) 'Liberation Ecology: Development, Sustainability, and Environment in an Age of Market Triumphalism', in R. Peet and M. Watts (eds) Liberation Ecologies. Environment, Development, Social Movements, pp. 1-45. London: Routledge.

Petersen, L. K. (1997) Miljobevidsthed på MTV. Om Naturen i Massekulturen. Copenhagen: Forlaget Sociologi.

Porter, G. and J. W. Brown (1996) Global Environmental Politics. Boulder, CO: Westview.

RAFI (Rural Advancement Foundation International) (1994) Conserving Indigenous Knowledge: Integrating Two Systems of Innovation. New York: United Nations Development Programme.

RAFI (1995) 'Biopiracy Update: A Global Pandemic'. RAFI Communiqué September/October 1995.

RAFI and Cultural Survival Canada (1997) 'Sangre de Drago', BioPirates Log 4. The Rural Advancement Foundation International (RAFI) and Cultural Survival Canada.

Raymond, G. and M. Fok (1995) 'Relations entre Coton et Vivriers en Afrique de l'Ouest et du Centre. Le Coton Affame les Populations: une Fausse Affirmation?', Economies et Sociétés. Série Développement Agro-alimentaire 22(3-4): 221-34.

Reid, W. V. et al. (1993) Biodiversity Prospecting: Using Genetic Resources for Sustainable Development. Washington, DC: World Resources Institute.

République du Mali (1985) Plan National de lutte Contre la Désertification et de l'Avancée du Désert, 1985-2000. Bamako: Direction Nationale des Eaux et Forêts.

Reyes, V. (1996) 'The Value of Sangre de Drago', Seedling 13(1): 16-21.

Ribot, J. (1995) 'Review of Policies in the Traditional Energy Sector: Mali Forestry Sector Policy Report'. Africa Technical Division, World Bank.

Ribot, J. (1999) 'Decentralisation, Participation and Accountability in Sahelian Forestry: Legal Instruments of Political-administrative Control', Africa 69(1): 23-64.

Rich, B. (1994) Mortgaging the Earth. London: Earthscan.

Robbins, P. (2000) 'The Practical Politics of Knowing: State Environmental Knowledge and Local Political Economy', Economic Geography 76: 126-44.

Roe, E. M. (1991) 'Development Narratives, Or Making the Best of Blueprint Development', World Development 19(4): 287-300. 
Roe, E. M. (1995) 'Except-Africa: Postscript to a Special Section on Development Narratives', World Development 23(6): 1065-9.

Roe, E. M. (1999) Except-Africa. Remaking Development, Rethinking Power. New Brunswick, NJ: Transaction Publishers.

Rowlands, I. H. (1995) The Politics of Global Atmospheric Change. Manchester: Manchester University Press.

Sandler, T. (1997) Global Challenges: An Approach to Environmental, Political and Economic Problems. Cambridge: Cambridge University Press.

Scott, J. C. (1998) Seeing Like a State. New Haven, CT, and London: Yale University Press.

Shackley, S. and B. Wynne (1995) 'Global Climate Change: The Mutual Construction of an Emergent Science-policy Domain', Science and Public Policy 22(4): 218-30.

Shaw Thacher, Peter (1979) 'Desertification: The Greatest Single Environmental Threat', Desertification Control Bulletin 2(1): 7-9.

Shiva, V. (1997) Biopiracy. The Plunder of Nature and Knowledge. Boston, MA: South End Press.

Stebbing, E. P. (1938) 'The Encroaching Sahara: The Threat to the West African Colonies', The Geographical Journal 85: 506-24.

Stott, P. (1999) 'Tropical Rain Forest: A Political Ecology of Hegemonic Mythmaking'. London: Institute of Economic Affairs.

Stott, P. and S. Sullivan (eds) (2000) Political Ecology: Science, Myth and Power. London: Arnold.

Svarstad, H. (2000) 'Local Interests and Foreign Interventions: Shaman Pharmaceuticals in Tanzania', in H. Svarstad and S. Dillion (eds) Responding to Bioprospecting: From Biodiversity in the South to Medicines in the North, pp. 145-53. Oslo: Spartacus.

Svarstad, H. (forthcoming) Bioprospecting: Global Discourses and Local Perceptions. Shaman Pharmaceuticals in Tanzania. Oslo: Centre for Development and the Environment, University of Oslo.

Swift, J. (1996) 'Desertification: Narratives, Winners and Losers', in M. Leach and R. Mearns (eds) The Lie of the Land: Challenging Received Wisdom on the African Environment, pp. 73-90. Oxford: James Currey.

Taylor, P. and F. Buttel (1992) 'How do we Know we have Global Environmental Problems? Science and the Globalisation of Environmental Discourse', Geoforum 23(3): 405-16.

Thompson, M. and S. Rayner (1998) 'Cultural Discourses', in S. Rayner and E. Malone (eds) Human Choice and Climate Change. Volume 1 The Societal Framework, pp. 265-343. Washington, DC: Batelle Press.

Turner, M. D. (1999) 'Conflict, Environmental Change and Social Institutions in Dryland Africa: Limitations of the Community Resource Management Approach', Society and Natural Resources 12(7): 643-57.

United Nations (1992) Convention on Biological Diversity. Nairobi: United Nations Environmental Programme.

Warren, A. and M. Khogali (1992) Assessment of Desertification and Drought in the SudanoSahelian Region 1985-1991. New York: UNSO.

Wigley, T. M. L., R. Richels and J. A. Edmonds (1996) 'Economic and Environmental Choices in the Stabilization of Atmospheric $\mathrm{CO}_{2}$ Concentrations', Nature 379(6562): 240-3.

Wilson, E. O. (1992) The Diversity of Life. Harmondsworth: Penguin.

World Bank (1996). Towards Environmentally Sustainable Development in Sub-Saharan Africa. A World Bank Agenda. Washington, DC: The World Bank.

World Bank (1999) World Development Report 1999. Washington, DC: The World Bank.

World Commission on Environment and Development (1987) Our Common Future. Oxford: Oxford University Press.

Yapa, L. (1996) 'What Causes Poverty? A Postmodern View', Annals of the Association of American Geographers 86(4): 707-28. 
The authors have worked on aspects of global environmental change for the past decade. Neil Adger is a lecturer in Environmental Economics, School of Environmental Sciences, University of East Anglia, Norwich, NR4 7TJ, UK. He is a Senior Research Fellow in CSERGE, a Programme Manager for the Tyndall Centre for Climate Change Research, both at University of East Anglia, and is a lead author in the Third Assessment Report of the IPCC on 'Impacts Vulnerability and Adaptation'. Tor A. Benjaminsen is a geographer and senior researcher at Noragric, Agricultural University of Norway. He carries out research on natural resources management, agriculture and land tenure in drylands Africa, particularly in Mali. Katrina Brown is a reader in the School of Development Studies and Senior Research Fellow in CSERGE at the University of East Anglia, Norwich, NR4 7TJ, UK. Her research has focused on forest and environmental policy and institutions. Hanne Svarstad is a sociologist and researcher at the Division for Man-Environment Studies, Norwegian Institute for Nature Research (NINA), Oslo. 